\title{
Marisa Musaio (2020). Dalla distanza alla relazione. Pedagogia e relazione d'aiuto nell'emergenza. Milano-Udine: Mimesis, p. 198
}

DOI: http://dx.doi.org/10.12775/PCh.2021.013

The care relationship is a crucial theme for pedagogical reflection, especially in today's context of social distancing. In the last year we have experienced a sudden and dramatic interruption of relationships conducted in person. We have been forced to review our ways of living with others, in circumstances of distance and separation. Musaio writes:

When we are deprived of the presence due to the absence of the other, at first we try to return to things, to experience and activities so as not to suffer from detachment and absence. These experiences anticipate 'clues' and prefigure 'routes' that are in some cases unforeseen, but which are always new. These are the clues that lead to deeper forms of awareness, for a human and existential regeneration that moves us away from the sense of escape from oneself and from others, which is a characteristic dimension of our age. Distance, lack and absence place us in a condition of imperfection, in the face of dark moments when the words of life seem to tremble because we feel that our convictions are no longer enough to hold together our securities (pp. 7-8).

We can trace these reflections in the first pages of the thought-provoking volume by Marisa Musaio, Associate Professor of General and Social Pedagogy at the Catholic University of the Sacred Heart of Milan. The book is significantly entitled From distance to relationship. Pedagogy and the helping 
relationship during the emergency, and motivates an in-depth reflection on three levels:

1) an attentive discussion of people's experiences, especially the most 'tiring' ones of life;

2) the resonance of these experiences within us, also expressed through significant references to poetry and literature;

3) the identification of pedagogical guidelines for educators and pedagogists who work in situations of difficulty, which ask them to create a caring and educational relationship that promotes the person and his/her potentialities.

The author leads the reader on a reflective path through which to address the profound questions raised by the relationship with oneself and others. Recovering the most authentic meaning of the helping relationship means learning to open oneself up to a hope horizon, which becomes an active commitment to education. The author writes: 'As pedagogical and educational professionals in different fields, we need to ask ourselves, what meaning has the relationship for us?'

As a human dynamic, relationships help us get closer to others: 'if it happens that the unforeseen events of life take a non-negligible role, they take shape, also in relation to our profession, as an opportunity to reconsider the fundamental themes, to take note of encounters and paths that can be generated from within the discontinuity that characterises us as human beings' (p. 9). Certainly this book asks the reader to be willing to meet his or her own and others' humanity, and to continually reinterpret three dimensions of the helping relationship: 1) the words of education; 2) the conditions of life and difficulties of each person; and 3 ) the search for horizons for interpreting the difficulties encountered and experienced by people (p. 10). Consequently, the educational relationship needs to overcome extraneousness and recover interiority.

The analysis is articulated within four chapters: the first, dedicated to the 'Forms of human discontinuity', highlights how this period is making us increasingly understand the essential fragility of the human being, and his/ her inevitably 'imperfect life' (p. 43), which is most dramatically evident in some life stories. Rather than a superficial perspective, social stigmatisation, and the reductionism of practices based only on procedures, the educator is asked to enter into these situations with relational and emotional wisdom, with the skill to recognise the wounds, and with the competence of listening 
to others and oneself, in order to open possibilities, and thereby help 'the person, despite the wounds and difficulties, to develop the viewpoint of a participatory approach to reality' (p. 35).

In the second chapter, entitled 'Forms of distance', the author, in continuity with the first, outlines the current forms of disease, in order to highlight the need to investigate them, and to underline the importance for each person to be supported on his or her existential path.

The text allows the reader to reflect on the fatigue of pain, death, the absence of relationships, and suffering. The paragraphs invite us to consider the formative possibilities of these experiences. 'The relationship of help preserves the intertwining with pain as a set of possibilities to transform it into a common possibility, as a common dimension, because we are all potentially suffering' (p. 86). However, in order to heal the wounds and to promote a perspective of proximity, it is necessary, as the author reminds us, that an educator is able to perceive the other (p. 75).

Thus, the third chapter is dedicated to the role of educator. In this regard, Marisa Musaio highlights the need for an educational profile characterised by an 'intimate resistance', which calls into question the dimension of personal interiority (see p. 118). The relationship of help is not just a matter of providing answers (see p. 88), but requires an introspection. The person capable of interiority can recognise the uniqueness of the other's history, without making it common to all (cf. p. 96). He or she can proceed within the limits and accompany the other on this educational path (p. 105). The educator can become a promoter of a peculiar pedagogical paradigm, who is capable of combining 'fragility and beauty'-that is, capable of grasping the primacy of the person and his or her potential to face the most complex situations (cf. pp. 121-122).

The fourth chapter presents the guidelines for a 'pedagogy of the helping relationship', to promote an anthropology of fragility that can overcome the illusory vision of human beings centred on the paradigm of the so-called 'strong man' (p. 129). The pedagogy of the relationship aims to activate educational processes that are capable of dealing with the 'limit', and can translate into concrete gestures of proximity and care. This book is not intended to provide instructions, but to reaffirm the commitment towards educational relationships. On the other hand, the volume asks a lot more from the reader who wants to be a promoter of proximity (see p. 177): to get involved in seeking the fundamental meanings of helping relationship in a difficult time, and be able to see the reality that lies beyond appearances. As Musaio rightly 
reminds us, the educational perspective requires not only methodological skills, but also a 'poetic' sensibility (see p. 15).

Pierpaolo Triani*

ORCID: 0000-0002-6640-5735

Milan, Italy

\begin{abstract}
Kamilla Frejusz. Wychowanie jako „dialog $i$ spotkanie” w myśli pedagogicznej Janusza Tarnowskiego. Studium hermeneutyczno-krytyczne. Warszawa: Wydawnictwo Naukowe Collegium Bobolanum, 2020, ss. 424
\end{abstract}

DOI: http://dx.doi.org/10.12775/PCh.2021.014

Opublikowana w 2020 roku książka dr Kamilli Frejusz jest efektem prowadzonych metodą hermeneutyczną badań, których przedmiotem była myśl pedagogiczna Janusza Tarnowskiego. Autorka postawiła pytanie o znaczenie dwóch kategorii: „dialogu” i „spotkania” dla sformułowanej przez Tarnowskiego koncepcji wychowania. Badania opisano w trzech częściach, treści przedstawiono w siedmiu rozdziałach. Metodologię badań zaprezentowano we wstępie. Jej prezentacja obejmuje wskazanie przedmiotu, celu i problemu głównego oraz problemów szczegółowych, jak również krótką charakterystykę metod hermeneutyki i fenomenologii. Całość pracy uzupełnia bogata bibliografia.

Dojrzałość pracy badawczej związana jest w pierwszym rzędzie z wyborem przedmiotu badań. Tak jest w przypadku niniejszego projektu. Po pierwsze, podejmując badania pedagogiczne, warto sięgnąć właśnie do filozofii wychowania, aby w ten sposób uchwycić jego istotę. W dobie dominacji badań empirycznych, zwłaszcza badań ilościowych, filozofia wychowania bywa zaniedbywana. Tymczasem wyniki owych badań - niezaprzeczalnie cenne - często nie dotykają istoty wychowania, pomijając tak nieuchwytne procesy, jak chociażby kluczowe dla myśli Tarnowskiego procesy dialogu czy spotkania. Filozofia wychowania pomaga uchwycić istotę wychowania

* Prof. Dr. Pierpaolo Triani, Full Professor of General and Social Pedagogy, Faculty of Education Sciences, Catholic University of Sacred Heart of Milan; email: pierpaolo.triani@, unicatt.it. 